\title{
平棚で栽培したマルバカイドウ台リンゴ樹における 果実収量と果実品質の経年変化
}

\author{
伊藤大雄 * \\ 弘前大学農学生命科学部附属生物共生教育研究センター 038-3802 青森県藤崎町藤崎
}

\section{Inter-annual Trend of Fruit Yield and Quality of Apple Trees with Marubakaido Rootstock Trained with Flat Trellis System}

\author{
Daiyu Ito* \\ Teaching and Research Center for Bio-coexistence, Faculty of Agriculture and Life Science, Hirosaki University, \\ Fujisaki, Fujisaki, Aomori 038-3802
}

\begin{abstract}
To develop a low-tree-height apple cultivation technique using a flat trellis system, large-sized nursery stocks of the apple cultivars 'Fuji', 'Tsugaru', and 'Koukou' with Marubakaido rootstock were planted under a 1.8- m- high flat trellis in 2004, at a density of 400 plants ha ${ }^{-1}$. They were then grown and trained following an $\mathrm{H}$-shaped pattern for 9 years, with fruit yield and quality evaluated annually. It was found that apple trees under the flat trellis system were high yielding in the first years compared with those under the conventional open center training system, because the fruit yield of the three varieties exceeded local average productivity $\left(22 \mathrm{t} \cdot \mathrm{ha}^{-1}\right)$ in the fifth or sixth years after planting, and two of them met local target productivity $\left(35 \mathrm{t} \cdot\right.$ ha $\left.^{-1}\right)$ in the ninth year. However, the average yield of each variety from the seventh to ninth years was $71-81 \%$ of the target productivity, which was lower than that of the adult trees under the open center training system. The fruit weight and soluble solids content of each variety increased annually, and fruits grown under the trellis system became larger than those grown under the open center training system, with soluble solids contents greater than $13^{\circ}$ or $14^{\circ}$ at the end of the study. A high number of water sprouts, however, emerged on trees under the flat trellis system, which led to a lower number of flower buds, particularly on the lateral shoots near the main stem, despite pinching and summer pruning being conducted. The decreased number of flower buds further resulted in a reduced fruit yield in the following years, therefore, the cultivation system used in this study should be improved to reduce water sprout emergence.
\end{abstract}

Key Words : flower bud, fruit weight, H-shaped training, high yielding in the first years, soluble solids content キーワード : 花芽, $\mathrm{H}$ 字形仕立て，一果重，早期成園化，糖度

\begin{abstract}
緒言
我が国のリンゴ栽培では, 現在, 省力化により労働生産 性を向上させ経営規模を拡大することが重要な課題となっ ている，そのためには，諸作業の機械化が望まれるが，摘 果，摘葉，玉まわし，収穫などの手作業が労働時間の $50 \%$ 以上を占めて扣り（青森県農林水産部，2016; 福田・増田, 2006）, 機械化は進展していない。この状況を打破するた めには, 低樹高化して脚立を伴う作業を減らし, 手作業の 効率を少しでも向上させる必要がある. 我が国では, 低樹 高化を図るために 1970 年頃からわい性台木の導入が続け られてきた。 しかしわい性台木を使用して子樹高は通常で $4 \mathrm{~m}$, 時には $5 \mathrm{~m}$ 近くに達し（福田, 1988), 従来のマルバカ
\end{abstract}

2017 年 7 月 10 日 受付. 2017 年 10 月 6 日 受理.

本報告の一部は園芸学会東北支部平成 22 年大会ならびに園芸

学会平成 26 年春季大会で発表した。

* Corresponding author. E-mail: daiyu@hirosaki-u.ac.jp
イドウ台木の開心形樹より高樹高となる場合も少なくな い.とりわけ積雪地ではわい性台木を用いて低樹高に仕立 てると雪害のリスクが高まる。このような事情を背景に, 特に積雪地ではわい性台木の導入が進展して扔らず， 10 アール当たり労働時間もこの 20 年間注とんど減少してい ない（青森県農林水産部，2016）.

平棚栽培は，二ホンナシに捛いては台風対策などのた め，またブドウやキウイフルーツなどのつる性果樹では枝 を誘引するため，古くから採用されてきた日本独特の栽培 法であるが，極めて低樹高に仕立てられているので諸作業 に脚立を全く必要とせず, 省力・軽労働化が期待できる. そのため上記以外の樹種でも各地で導入が試みられるよら になってきた。 カキでは福岡県に拈いて，林ら（2004）が 樹幹の切り下げにより，また藤島ら（2006）が高接ぎ品種 更新により立木仕立てから平棚仕立てに移行させたとこ ろ, 平棚仕立て移行樹は立木樹より面積当たり収量や 1 果 重が優れていた． 和歌山県では樹幹を切り下げることなく 
既存の主枝を棚面まで下方誘引することでカキ樹の平棚仕 立てへの移行が試みられ，その省力性が実証されたほか， 果実品質の向上も確認された（川尾ら，2005）。モモでは 熊本県に打いて，まずビニールハウスへの導入が試みられ (岡田ら, 1996), 続いて露地栽培樹を樹形改造して平棚栽 培に移行させる試験（岡田・益田，2000）が実施されて, 省力性や早期多収性が実証された，そのほか，群馬県にお いてスモモとウメの平棚栽培法が考案され（松波，2003; 松波ら，1998）, 収穫作業の省力化はもとより, 収量や一 果重の増大がはかられている。

リンゴに扔ける平棚栽培の実証的な研究は，著者の知る 限り実施されていないが，Y字棚（波状棚）を利用した場 合には早期多収性が立証されている。米国に执いて M.26 台木のリンゴ樹を Y 字棚の凹部に栽植し，棚面に斜立主 枝 $8 \sim 10$ 本を車枝状に誘引配置する樹形により，植光付 後 10 年間の累積収量がわい性台木，強勢台木のいずれ の主幹形樹にも勝ることが報告されている（Robinsonら， 1991）。我が国でも倉橋・高橋（1994）が M.26台木のリン ゴ樹を $\mathrm{Y}$ 字形の 2 本主枝に仕立て，側枝を $\mathrm{Y}$ 字棚に誘引 することにより，植え付け 9 年目には主幹形樹の 1.3 倍の 収量を得た。しかし，Y字棚を利用した樹の樹高は，主幹 形樹よりは低いものの $2.5 \sim 3.5 \mathrm{~m}$ に達し諸作業には脚立 が必要となる。

著者らは，リンゴ樹を脚立作業が不要となるような低樹 高に仕立てる可能性を追究する目的で，様々な樹種で導入 が進められている平棚栽培をリンゴでも検討しようと考 え，2004 年に園地を造成し，毎年調査データを蓄積して きた。しかし，試験園が成園化した直後の 2013 年 2 月に， 試験地では観測史上最高となる $153 \mathrm{~cm}$ の積雪に見舞われ， 平棚が積雪荷重により倒壊した。本報では，2012年（植 付 9 年目)までの果実收量と果実品質の経年変化を報告す るとともに，平棚栽培の導入に向けて残された問題点を考 察する.

\section{材料および方法}

\section{1. 大苗の育成}

本研究では，早期多収を狙いとして市販の苗木をさらに 2 年間苗圃で育て，大苗を育成してから棚下に定植した. すなわち，2002年 4 月に“家じ’ 25 樹，“つがる’ 7 樹打よ び こうこう’ 7 樹の市販苗（台木：マルバカイドウ）を 弘前大学農学生命科学部附属生物共生教育研究センタ一藤 崎農場（青森県藤崎町）の苗圃に植兄付け，主幹を地上高 $1 \mathrm{~m}$ で切り戻した（第 1 図 A)。2003 年 4 月には，前年伸長 した新梢の中から最も旺盛な 2 本を選んで主枝候補枝と し，支柱を添えて水平から $60^{\circ}$ の角度に誘引するとともに， $1 \mathrm{~m}$ 以上伸長している場合は基部から約 $1 \mathrm{~m}$ のところで切 り戻した。 また，それ以外の新梢はすべて基部から剪除し た（第 1 図B）。2004 年 4 月には第 1 図 C のような樹姿と なった。

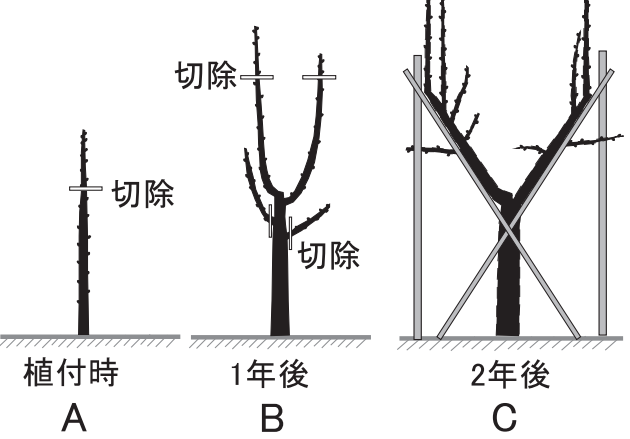

第 1 図平棚栽培供試樹の大苗育成方法

\section{2. 定植後の供試樹数と目標樹形}

育成した大苗の中から，生育のよい“ふじ’ 20 樹，“つが る’6樹招よび こここう’4 樹を選んで，棚面の高さが $1.8 \mathrm{~m}$ の平棚の下に定植した。試験実施場所は苗戋と同じ く弘前大学藤崎農場である。栽植距離は樹間 $5 \mathrm{~m}$, 樹列間 $5 \mathrm{~m}\left(400\right.$ 樹・ $\left.\mathrm{ha}^{-1}\right)$ とした．樹形は，いわゆる $\mathrm{H}$ 字形整枝 （加藤ら，1999; 岡田・益田，2000）により，成園化した時 に第 2 図に示すよらな形態になることを目標とした。すな わち, 主幹から約 $40^{\circ}$ の角度で斜立させた 2 本の主枝のそ 孔艺れを，棚面に達したところで 2 方向に分岐させて 4 本 主枝とし，以降主枝を上から見ると $\mathrm{H}$ 字形になるよう， 棚面に沿ってそれぞれを水平に伸長させた。ただし，各主 枝の先端は勢いを保つために斜立させた。な拉，正確に表 現するなら上記 4 本のらち 2 本は亜主枝であるが，本研究 では亜主枝と主枝延長部が完全に等しい大きさになり区別 できないため，4本とも主枝と呼称することにする，植付 7 年目（2010年）頃より主枝の先端が隣接樹の主枝の先端 と接触するようになり，注涪目標樹形に到達した。研究は その後も継続したが，2013 年 2 月に積雪荷重により平棚 が倒壞したため中止した。

主枝の両側には約 $40 \mathrm{~cm}$ 間隔で長さ $1 \mathrm{~m}$ あるいは $1.5 \mathrm{~m}$ の側枝（成り枝）を配置するようにした。側枝は棚面に誘 引後, さらに $1 \sim 2$ 年かけて目標の長さ $(1 \sim 1.5 \mathrm{~m})$ まで伸 長させた。

第 2 図のと打りに樹形を完成させると総側枝長は $60 \mathrm{~m}$

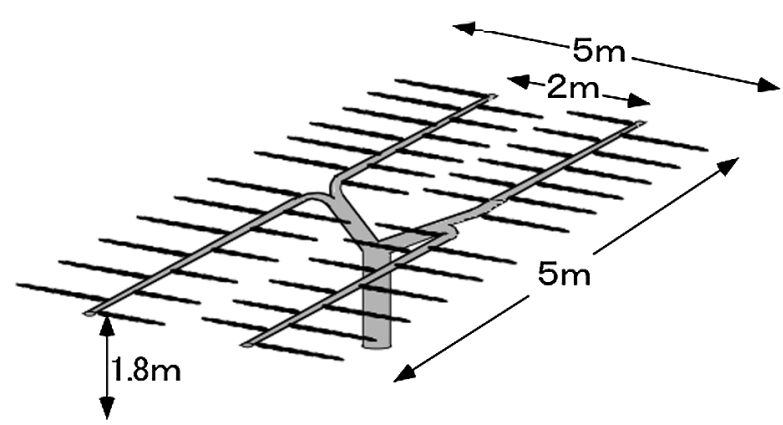

第 2 図平棚栽培供試樹の目標樹形（ $\mathrm{H}$ 字形仕立て） 
となり，側枝長 $20 \mathrm{~cm}$ につき $300 \mathrm{~g}$ の果実 1 個を結実させ ることにより 1 樹から 300 個，90 kg の果実を収穫するこ とが期待できる. これは $36 \mathrm{t} ・ \mathrm{ha}^{-1}$ に相当し, 計算上は青 森県の目標収量である $35 \mathrm{t} ・ \mathrm{ha}^{-1}$ を達成できる.

\section{3. 新梢管理と着果・着色管理}

定植当年（2004年）は，わずかに着果する個体もあっ たが，すべて摘果した。植付 4 年目（2007年）までは，主 枝の棚下部分から発生した枝を 1 樹当たり数本, 側枝とし て残し着果させたが，5年目に“ふじ’ 4 樹の棚下側枝をす べて剪除して，その影響を調査した。そして 6 年目 (2009 年）以降は原則として全樹の棚下側枝を剪除し，棚面上の 側枝だけに着果させるようにした。

全研究期間を通じ, 供試した 3 品種のすべてについて, 生育期間中に主枝の背面から著しい徒長枝の発生が認めら れた。そのため，7〜8月に夏季剪定を必ず 1 回は実施し， 旺盛な徒長枝を剪除した。

徒長枝は，主枝の背面ばかりでなく側枝の背面からも大 量に発生し，側枝の維持を困難にするばかりでなく花芽の 確保にも影響した。 そこで 5 年目（2008年）と6 年目 (2009 年）に一部の樹を供試して摘心試験を実施したところ，花 芽数を増大させる効果が認められたので（伊藤ら，2010）, 6 年目（2009年）以降は6〜 月に少なくとも 1 回，側枝 上に発生した $15 \mathrm{~cm}$ 以上の新梢をすべて基部 $5 \mathrm{~cm}$ を残し て切除する摘心処理を実施した。な执，“ふじにについて は，摘心処理を実施しても果実着色期に棚面が暗くなるほ ぞ徒長枝が発生している場合があり, 必要に応じて果実着 色期にも徒長枝を基部から剪除した。

摘果は2 回に分けて実施し, 果実が密生している所は最 終的に 4 頂芽に 1 果, あるいは側枝長 $20 \mathrm{~cm}$ に 1 果程度に 制限した. 果実は, 枝齢 2 年以上の側枝に着生する短果枝 や中果枝の頂芽に結実させ，えき芽には結実させなかっ た. 果実の着色促進のための摘葉は, “ふじ’ とつがる’ について, 収穫日の $15 ３ 0$ 日前に実施した.

\section{4. 収穫果実の調査}

植付 2 年目（2005 年）から9 年目（2012 年）まで毎年, 11 月上旬（“ふじと とこらこら’）あるいは9月中旬（“つ がる’）にすべての果実を収穫し，樹ごとに果実数と総果 実重を調查して ha 当たりの果実収量と平均 1 果重を計算 した。な技，5年目（2008年）だけは，棚面の果実と棚下 の果実を区別して収穫した。ささらに，着色や果実重量が中 庸な果実を20果（“ふじ’），12 果（“つがる’），あるいは 8 果 ( こうこう’) 程度選び, 果実赤道面の 2 箇所から果 肉を少量採取して, 搾汁の上デジタル糖度計（PAL-1, (株)アタゴ）により糖度を測定した。

試験園は，植付直後の 2005 年と2006 年にも記録的な積 雪に遭遇し（最深積雪はそれぞれ $150 \mathrm{~cm}, 139 \mathrm{~cm}$ ), 棚面 を残してほぼ全体が雪の下に埋もれたため, 一部の樹では 野鼠の食害を受けた主幹や主枝を作り直すこととなった. とりわけ“ふじ’ 3 樹は被害が激甚で，2008年あるいは
2009 年まで果実が収穫できなかったため, 収量の計算に 当たってはこの 3 樹を一貫して除外した.

本研究では，開心形仕立て・マルバカイドウ台木で，同 じ樹齢の樹を用意できなかった，そのため，対照樹として は必ずしも適当ではないが，藤崎農場内に樹間 $9 \mathrm{~m}$, 縦列 間 $9 \mathrm{~m}$ で栽植された開心形仕立て・マルバカイドウ台木の ‘らじ’（1980年植え付け. 最終調査年の 2012 年が植付 33 年目に相当する）より毎年生育中庸な 3 樹を選び，樹ごと に果実数と総果実重を測定するとともに，着色や果実重量 が中庸な 15 果程度の糖度を測定して比較対象とした。

\section{5. 花芽数の調査}

2010 年 12 月に，“ふじ’ 4 樹から，先端新梢を除いて長 さが $75 \mathrm{~cm}$ 以上ある側枝を 31 本選び，それぞれ主枝上の 発生位置を記録した。そして各側枝について，1 年生部位 (2009 年に伸長した部位)，2 年生部位と 3 年生以上の部位 に区分して部位ごとの側枝長を測定後，各部位に着生して いる頂芽花芽数を計測した。その際，実体顕微鏡による予 備観察を踏まえて，直径が目視で $4 \mathrm{~mm}$ 以上あり丸みを帯 びた芽を花芽と判定した.

\section{結果}

\section{1. 収量の推移}

植付 2 年目（2005 年）から9 年目（2012年）までの単位 面積当たり果実収量（単収）の経年変化を品種ごとに第 3 図に示した。 また比較のため開心形“らじ”成木の各年 （植付 $26 \sim 33$ 年目）の単収も第 3 図に示した。平棚で栽 培された 3 品種の単収は $2 \sim 4$ 年目（2005～2007年）にか 汀て毎年増大した． 5 年目（2008年）は，青森県において 過去 16 年間（2001 2016年）でリンゴが最も高単収の年 であり，本実験の ‘らじ’ と‘つがる’でも同年に単収が 急増して $22 \mathrm{t} ・ \mathrm{ha}^{-1}$ を突破した。 ‘こうこう’は他の2 品種 より収量の経年的増大が遅れたが，6年目（2009年）に $25.87 \mathrm{t} ・ \mathrm{ha}^{-1}$ を記録した。 その後は，7年目（2010年）頃

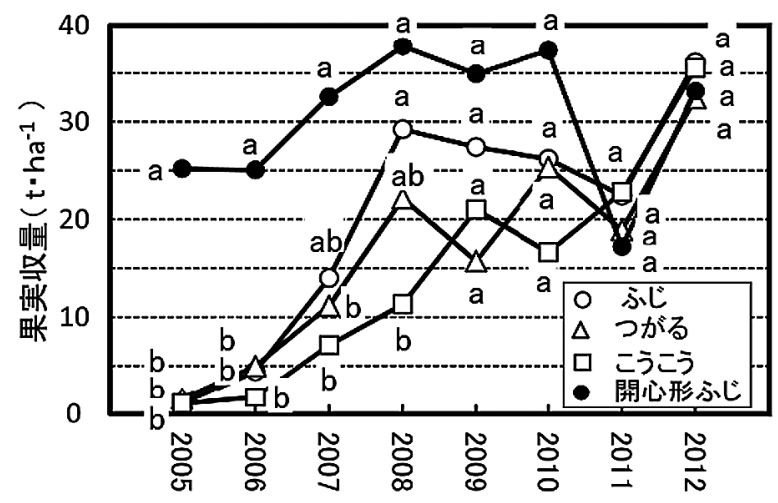

第 3 図 2004 年に植え付けた平棚栽培リンゴ樹の品種別・年 次別果実収量

比較のため開心形 ‘ろじ’（1980 年植付. 植付 26〜 33 年目）の果実収量も示す

同一年次の同じ文字間には Tukey 検定により $5 \%$ 水準 で有意差がないことを示す 
に樹冠の拡大が停止し，8年目（2011年）は青森県に括い て過去 16 年で最も低単収の年となったこともあって, 平 棚栽培樹の単収も頭打ちが続いた. しかし9年目(2012 年）は再び単収が急増して $32.40 〜 36.08 \mathrm{t} ・ \mathrm{ha}^{-1}$ を記録し た. 目標樹形到達後の 3 年間（2010～2012 年）について 見ると, 平棚で栽培した 3 品種の単収は, 開心形 ‘らじ’ 成木との間に有意な差は認められなかった。 しかし, 上記 3 年間の平均単収は ‘らじ’ で $28.24 \mathrm{t} ・ \mathrm{ha}^{-1}$, ‘つがる’で $25.56 \mathrm{t} \cdot \mathrm{ha}^{-1}$, ‘こうこう’で $24.99 \mathrm{t} \cdot \mathrm{ha}^{-1}$ であり, いずれも 開心形 ‘怘じ’ 成木の 8 年間（2005～2012 年）の平均単収 $\left(30.40 \mathrm{t} \cdot \mathrm{ha}^{-1}\right)$ と比べて若干少なく, 青森県の目標単収 $\left(35 \mathrm{t} ・ \mathrm{ha}^{-1}\right)$ の 71 ～81\%にとどまった.

\section{2. 平均 1 果重の推移}

植付 2 年目（2005 年）から9 年目（2012年）までの平均 1 果重の経年変化を品種ごとに第 4 図に示した. また比較 のため, 平棚試験園が㟫涪成園化した 2009 年以降の開心 形 ‘ふじ’成木の平均 1 果重も第 4 図に示した. 平棚で栽 培された 3 品種の平均 1 果重は, 2 年目（2005 年）は $250 \mathrm{~g}$ 前後と低かったが，“ふじ’では 5 年目（2008年）まで, ‘がる’と“こうこう’では 6 年目（2009年）まで年次の 経過とともに増大し, 5 年目以降は 3 品種とも $310 \mathrm{~g}$ 以上 で推移した. 6 年目以降の平均 1 果重は開心形“ふじ”樹 を上回ることが多かった。

平均 1 果重は摘果強度の影響を受けることが知られて括 り, 一般に強く摘果すると単収は低下寸るが平均 1 果重は 増大する，そこで目標樹形がほぼ完成した 6 年目 (2009 年）以降について，単収と平均 1 果重の関係を検討して 第 5 図に示した。 また比較のため開心形 ‘らじ’樹の調査 結果（2009年以降）も第 5 図に併せて示した. 平棚で栽培 した 3 品種では, 平均 1 果重は低収量年ほど高く, 3 品種 を込みにした平均 1 果重と単収の間には有意な負の相関関 係が認められた。一方, 開心形 ‘ふじ’ 樹では, 両者の間 に明瞭な関係が認められず，総じて平棚で栽培された 3 品

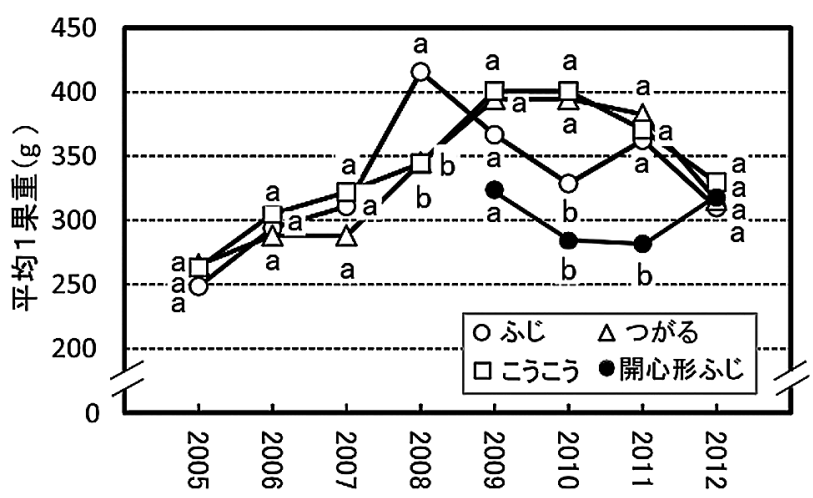

第 4 図 2004 年に植え付けた平棚栽培リンゴ樹の品種別・年 次別平均 1 果重

比較のため 2009～2012 年の開心形 ‘ふじ’（植付 30～ 33 年目) の平均 1 果重も示す

同一年次の同じ文字間には Tukey 検定により $5 \%$ 水準 で有意差がないことを示す

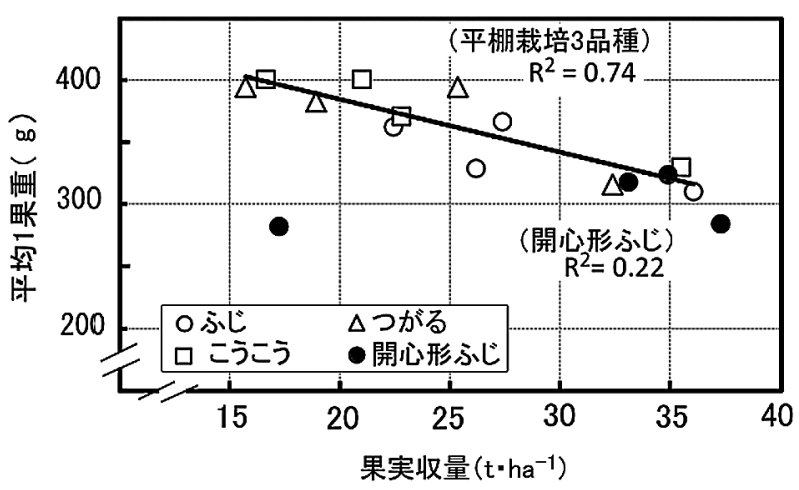

第 5 図 平棚栽培リンゴ樹の単位面積当たり果実収量と平均 1 果重の関係（2009～2012 年）

比較のため開心形 ‘らじ’ のデータ（2009～2012 年. 植付 $30 \sim 33$ 年目) も示す

第 1 表 棚面下側枝の切除が収量と平均 1 果重に及ぼす影響 (2008 年)

\begin{tabular}{ccccccccc}
\hline \hline \multirow{2}{*}{$\begin{array}{c}\text { 棚面下 } \\
\text { 側枝 }\end{array}$} & \multicolumn{3}{c}{ 収量 $\left(\mathrm{t} \cdot \mathrm{ha}^{-1}\right)$} & & \multicolumn{3}{c}{ 平均 1 果重 $(\mathrm{g})$} \\
& & 棚面 & 棚面下 & 全体 & & 棚面 & 棚面下 & 全体 \\
\hline 残存 & 24.81 & 5.71 & 30.52 & & 417 & 342 & 400 \\
切除 & 25.16 & 0.00 & 25.16 & & 458 & - & 458 \\
\hline
\end{tabular}

種より平均 1 果重が低かった. そのため平棚で栽培された 3 品種は, とりわ低収量年に打いて, 開心形 ‘灾じよ り大果を生産する傾向が認められた.

\section{3. 棚下側枝の生産性 (5 年目)}

植付 5 年目（2008 年）の ‘らじ’に括いて，棚下側枝を すべて切除した樹と棚下側枝を残した樹の生産性を第 1 表 に示した，棚下側枝を残した場合でも，棚下から収穫され る果実は $5.71 \mathrm{t} ・ \mathrm{ha}^{-1}$ にすぎず，その平均 1 果重も $342 \mathrm{~g}$ と， 棚上果実より $75 \mathrm{~g}$ も少なかった。棚下側枝を切除した樹 では, 残された棚上側枝の平均 1 果重が増大し, 収量も棚 下側枝残存樹の棚上部分を上回ったが，棚下側枝残存樹の 全体収量には及ばなかった。

\section{4. 糖度の推移}

植付 3 年目（2006年）から9年目（2012年）までの平均 果実糖度の経年変化を品種ごとに第 6 図に示した。 また比 較のため開心形 ‘らじ’成木の 2009～2012 年の平均果実 糖度も第 6 図に示した。平棚で栽培した 3 品種の糖度は, 8 年間を通して ‘じ’が最も高く, ‘つがる’および ‘う こら’との間に，しばしば有意な品種間差が認められた. また, いずれの品種でも, 若木のうちは糖度が低かったが 経年的に糖度が上昇した。“ふじ’では2010 年以降 $14^{\circ}$ 以 上の，“つがる’抌よび ‘らこう’では2011年以降 $13^{\circ}$ 以 上の糖度が確保された。平棚で栽培した ‘じ’と開心形 ‘らじ’ 樹の果実糖度を比較すると, 年次によって前者が 勝る場合や後者が勝る場合があり, 一定の傾向は認められ なかった。 


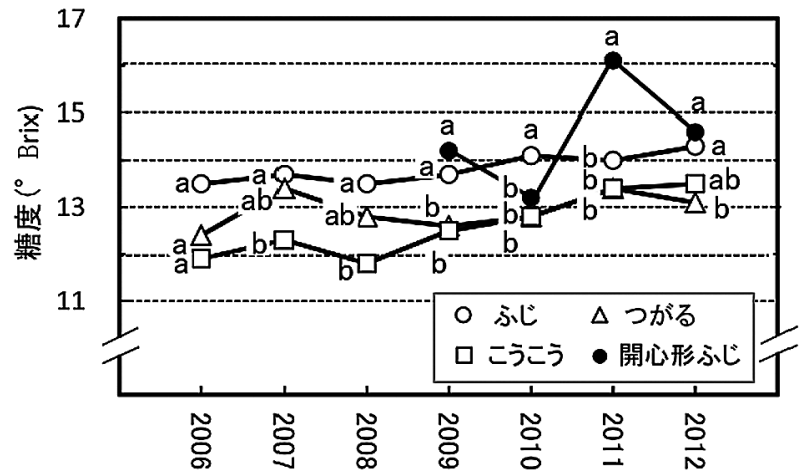

第 6 図 2004 年に植え付けた平棚栽培リンゴ樹の品種別・年 次別果実糖度 (Brix)

比較のため 2009〜2012 年の開心形 ‘ふじ’（植付 30〜 33 年目) の果実糖度も示寸

同一年次の同じ文字間には Tukey 検定により 5\%水準 で有意差がないことを示す

第2表 側枝の発生位置が花芽着生密度に及ぼす影響（2010年）

\begin{tabular}{|c|c|c|c|c|c|}
\hline \multirow{2}{*}{$\begin{array}{l}\text { 側枝発生位置 } \\
\text { (主枝分岐点から } \\
\text { の距離 : cm) }\end{array}$} & \multirow{2}{*}{$\begin{array}{l}\text { 調查 } \\
\text { 枝数 }\end{array}$} & \multicolumn{4}{|c|}{ 花芽着生密度 $\left(\right.$ 個・ $\left.\mathrm{m}^{-1}\right)$} \\
\hline & & $\begin{array}{l}1 \text { 年生 } \\
\text { 部位 }\end{array}$ & $\begin{array}{l}2 \text { 年生 } \\
\text { 部位 }\end{array}$ & $\begin{array}{c}3 \text { 年生以上 } \\
\text { 部位 }\end{array}$ & $\begin{array}{l}\text { 側枝 } \\
\text { 全体 }\end{array}$ \\
\hline $0-50$ & 9 & $10.7 \mathrm{a}^{\mathrm{z}}$ & $15.0 \mathrm{a}$ & $16.5 \mathrm{a}$ & $14.8 \mathrm{a}$ \\
\hline $50-100$ & 9 & $26.0 \mathrm{a}$ & $20.5 \mathrm{a}$ & $20.9 \mathrm{a}$ & $20.6 \mathrm{ab}$ \\
\hline $100-150$ & 7 & $16.8 \mathrm{a}$ & $23.4 \mathrm{a}$ & $28.4 \mathrm{a}$ & $23.5 \mathrm{~b}$ \\
\hline $150-200$ & 6 & $19.2 \mathrm{a}$ & $18.1 \mathrm{a}$ & $17.7 \mathrm{a}$ & $18.5 \mathrm{ab}$ \\
\hline
\end{tabular}

$\mathrm{z}$ 同一列の同じ文字間には Tukey 検定により 5\%水準で有意 差がないことを示す

\section{5. 花芽の着生}

調査対象とした側枝を, 側枝発生位置の主枝分岐点（棚 面に到達した主枝が 2 分される点）からの距離に応じて 4 群に分類し, 群別・部位別に花芽着生密度を計算して 第 2 表に示した。側枝上の部位別に花芽着生密度を比較す ると, 基部（3 年生以上部位）の方が着生密度が高い場合 も, 先端部 ( 1 年生部位) の方が着生密度が高い場合もあっ て，一定の傾向は見いだせなかった。 しかし側枝発生位置 が主枝分岐点から 0-50 cm の群は, 側枝上のどの部位を とっても, 花芽着生密度が他のどの群よりも少なかった。 同群の花芽着生密度は側枝全体で 14.8 個・ $\mathrm{m}^{-1}$ で, 最も花 芽が多い 100-150 cm の群と比較すると有意な差が認めら れた。

\section{考察}

青森県のリンゴ園の平均的な果実収量は, 近年扮よそ $22 \mathrm{t} \cdot \mathrm{ha}^{-1}$ である（青森県農林水産部，2016）。本研究では, ‘ふじ’とつがる’で植付 5 年目に, こうこう’で植付 6 年目に, 収量が $22 \mathrm{t} \cdot \mathrm{ha}^{-1}$ を突破した。 そして 7 年目頃 に目標樹形に到達し，9年目には ‘㤩じと こうこう’に 扮いて青森県の目標 $\left(35 \mathrm{t} ・ \mathrm{ha}^{-1}\right)$ を超兄る収量を記録し た. ところで開心形仕立てのリンゴ園は，栽植密度が 123 樹・ha ${ }^{-1}$ の場合は成園化するのに植付後 15 年以上を要し た事例（塩崎ら，1988）がある注か，栽植密度が 180 樹・ $\mathrm{ha}^{-1}$ でも成園化するまでに植付から 15 年程度を要すると されている（横田，2000）。一方塩崎ら（1988）は，マルバ カイドウ台の 3 年生の苗木を 417 樹・ $\mathrm{ha}^{-1}$ の密度に植光付 け，主幹形に整枝したところ，植付 5 年目には盛果期に到 達したと報告している。本研究でも，市販の苗木をさらに 2 年間苗圃で養成した後, 平棚施設に定植した。 また，栽 植密度も 400 樹・ $\mathrm{ha}^{-1}$ と，マルバカイドウ台のリンゴ園と してはやや高めにした，早期成園化を狙ったこのような試 久が, 本研究でも一定程度成功したものと考光られる。 た，平棚栽培では成り枝を平面的に誘引配置するため，樹 冠占有面積の拡大が早い。 カキ（林ら，2004）やモモ（岡 田ら，1996）では，平棚栽培において早期成園化が実現し た要因として，樹冠占有面積の早期拡大が指摘されて扔 り，本実験でも早期成園化の一要因と考兄られる.

平棚栽培リンゴ樹の平均 1 果重は, 結実開始年やその直 後は低かったが, 経年的に増大し, 植付 6 年目以降は開心 形仕立ての成木に勝ることが多かった，平棚栽培では低収 量年に目標と招りの果実数が確保できなかった個々の果実 が肥大した可能性も考兄られたが，開心形樹では低収量年 であっても平均 1 果重が増加する傾向はなかった（第 5 図)。また糖度についても，年次の経過とともに上昇する 傾向が見られ，最終的には $14^{\circ}$ あるいは $13^{\circ}$ 以上が確保さ れて，開心形樹と比べても遜色なかった．以上のことか ら，平棚栽培のリンゴ樹は，成木に到達すれば開心形樹よ り大玉化しやすく，かつ相応の糖度の果実を生産できると 考光られる.

一方，本研究を通じて浮き彫りになった平棚栽培の問題 点は，(1）目標樹形が完成し，樹冠がほぼ棚面全体を覆い 尽くすようになって子単収は目標の 8 割前後にとどまり, 開心形樹に及ばなかったこと，(2) 徒長枝の発生が極めて 多く, $6 \sim 7$ 月に摘心， $7 \sim 8$ 月に夏季剪定を丁寧に実施し ても，果実着色期には再度徒長枝の剪除が必要になる場合 があったこと,である。このうち第 1 の問題点, すなわち 低単収の原因は, 果実 1 個 1 個の大きさではなく果実数の 少なさである。既に明らかにしたように平棚栽培樹の平均 1 果重は開心形樹より大きく, 当初の想定 $(300 \mathrm{~g})$ をも上 回った. しかし 1 樹当たりの平均收穫果実数を第 3 図と第 4 図から計算すると, 目標と扮りの樹形に到達した後の 2010２012年でも204果（‘ふじ’，181果（‘がる’） 抢よび188果（“こうこう’）で，当初の想定（300果）に 遠く及ばなかった。 モモ（岡田ら，1996），カキ（藤島ら， 2006; 林ら，2004）， ウメ（松波，2003）, 入モ乇（松波ら， 1998）など，多くの果樹では平棚栽培の導入で着果数が増 大したり結実が安定することが報告されて扔り，本研究は これらの報告とは異なる結果となった。

リンゴ平棚栽培に打ける果実数の不足は，上述した第 2 の問題点，すなわち前年度に打ける徒長枝の多発が深く関 
与していると考えられた. 側枝背面からの徒長枝の多発 は，本来短果枝となって頂芽に花芽が形成されるべき枝の 多くが徒長し，花芽を形成しないために花芽数が減少す ることを意味する．本研究では著しく徒長する前の $6 〜 7$ 月に摘心処理を実施したので, 数 $\mathrm{cm} \sim$ 十数 $\mathrm{cm}$ 伸長した 再発枝の先端に花芽が形成される場合もあったが（伊藤 ら，2010)，十分な数の花芽を確保することはできなかっ たために，翌年の果実数の減少につながったものと考えら れる。

平棚栽培樹の平均 1 果重は開心形樹より大きかったこと から，隣接する徒長枝の光合成産物が果実に転流して個々 の果実を肥大させた可能性も考兄られる. しかし実際に は，モモに扣いて隣接する新梢からの光合成産物の転流は 汇とんど起こらないことが知られている（Volpeら, 2008). 従って, 徒長枝の多発は総合的に見れば翌年の果実数を減 少させて樹を低収量へと導き，加えて棚面への光の透入を 悪化させ果実の着色にも悪影響を及ぼすため, 克服すべき 重大な欠点だといえよう。ささに, 徒長枝が剪除されずに 冬季まで持ち越された場合, 積雪地では棚面上への積雪を 助長することになる，緒言で述べたように，本実験に供し た平棚施設は，記録的な大雪に見舞われた 2013 年に積雪 荷重のため倒壊したが, 同じ平棚施設でもニホンナシが栽 植されていた箇所は倒壊を免れた. まさに, 徒長枝の多発 が平棚施設の倒壊を誘発し, 本研究の続行を不可能にした 要因であるといってよい.

花芽は，主枝分岐点からの距離が 0-50 cm の側枝群，す なわら主幹からの距離が最も近い側枝上で最も少なかっ た. 本研究では徒長枝発生密度の調査を実施しなかった が，一般に徒長枝は主幹に近い所ほど発生が多い。本研究 でも 0-50 cm の群では目視的に徒長枝の発生が多く, 花芽 数が少なかったのは徒長枝の多発が関係していると考兄ら れた。なお，第 2 表によると0-50 cm の群でも側枝長 $1 \mathrm{~m}$ 当たり 14.8 個，すなわち側枝長 $6.8 \mathrm{~cm}$ に 1 個の割合で花芽 が着生していた。側枝長 $20 \mathrm{~cm}$ に 1 個の果実を着果させる には土分な花芽数に思えるが, 実際には花芽は著しく偏在

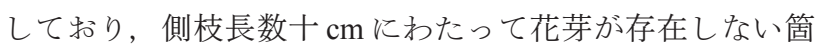
所が多数あった.

以上のことから, 本研究を踏まえたリンゴ平棚栽培の今 後の最重要課題は, 可能な限り徒長枝の発生を抑えて花芽 数と果実数を確保し，十分な収量に結びつけることであ る. これは，夏季剪定执よび摘心労力の軽減や，棚面の採 光改善にも結びつく. 脚立不要の低樹高栽培を目指してい るため, 徒長枝の多発はやむを得ない一面もあるが，以下 の 4 つの改善策が考えられる.

第 1 は, 栽植密度が高すぎて強剪定せざるを得ないこと が徒長枝多発の根本的原因と考えられることから, 現在よ り疎植にすることである。 しかし, 栽植密度を減じれば樹 冠の完成が遅れ，早期多収性が失われると予想される。そ のため, 予め永久樹と間伐予定樹を決めて現在と同じ程度
の密度で植え付け，適切な時期に間伐予定樹を間引く方法 (計画密植) 女考光られる.

第 2 は, 主幹近くの主枝から直接側枝をとることをやめ, 開心形樹の一般的な整枝法に倣って亜主枝を設けることで ある。

第 3 は，強勢台木（マルバカイドウ）でなくわい性台木 を用いることである，台木を变更すれば栽植密度を再検討 する必要がある.

第 4 は, 樹体ショョイント栽培（神奈川県農業技術セン ター，2010）を導入することである. すなわち，主幹ある いは主枝の延長枝が隣接樹と交差したら，隣接樹の主幹あ るいは主枝に接ぎ木して接続して樹勢を落ち着かせる。接 ぎ木後は，樹冠面積を減じることなく間伐することも可能 である、な抏，樹体ジョイント栽培を導入するならば，樹 型もこの栽培法に適したものに変更する必要がある.

現在，倒壊した平棚施設を改修し，上記の改善策を実証 するために新たな戋場実験を実施している.

\section{摘 要}

平棚を利用した低樹高栽培によりリンゴ栽培の省力化を 図るため, 2004 年にマルバカイドウ台木の ‘ふじ’ ‘つが る’ならびに こらこう’の大苗を合わせて 30 本，高さ $1.8 \mathrm{~m}$ の平棚施設に 400 樹・ $\mathrm{ha}^{-1}$ の密度で定植し, $\mathrm{H}$ 字形仕 立てに整枝しながら 9 年間にわたって収量や果実品質など を調査した。 各品種の収量は植付 $5 \sim 6$ 年目に現地の平均 収量 $\left(22 \mathrm{t} ・ \mathrm{ha}^{-1}\right)$ を超光, 植付 9 年目には 2 品種が現地の 目標収量 $\left(35 \mathrm{t} ・ \mathrm{ha}^{-1}\right)$ に到達するなど, 開心形仕立てに比 ベて早期成園化が実現した. しかし，7〜9年目の平均収 量は目標収量の $71 〜 81 \%$ にとどまり，成木の開心形樹よ り劣った. 平均 1 果重と糖度は各品種とも経年的に増加し, 研究終了時には開心形樹より大玉で平均糖度が $13^{\circ}$ あるい は $14^{\circ}$ 以上の果実が生産された。一方, 平棚栽培のリンゴ 樹は徒長枝の発生が極めて多く, 摘心や夏季剪定を実施し て対応したが，とりわけ主幹近くの側枝における花芽の減 少を招いた。 さらに花芽の減少は翌年の果実数の不足と低 収量につながった。 そのため, 今後の課題として，徒長枝 の発生が抑制されるよらに栽培体系を改良する必要性が認 められた。

謝 辞 本研究の実施に当たって有益な助言を頂いた弘 前大学名誉教授・塩崎雄之輔博士と, 収穫調查に協力して 頂いた弘前大学農学生命科学部果樹園芸学教室の学生諸氏 に深く感謝します。

\section{引用文献}

青森県農林水産部. 2016. 図説 農林水産業の動向 統計 資料. 〈http://www.pref.aomori.lg.jp/soshiki/nourin/nosui/ files/H26toall.pdf $\rangle$.

藤島宏之・矢羽田第二郎・松田和也・千々和浩幸・林 公 彦. 2006. 平棚仕立て法による栽培を行ったカキ ‘ 
秋’ の着花特性と収量, 果実品質. 福岡農総試研報. 25: 83-87.

福田博之. 1988. リンゴの低樹高栽培の現状と問題点. 農

林水産研究ジャーナル. 11: 12-16.

福田博之・増田哲男. 2006. リンゴ栽培における省力化の

現状. 果樹研報. 5: 1-13.

林 公彦・牛島孝策 ・千々和浩幸 - 姫野周二. 2004. 力キ “松本早生富有”の平棚仕立て法に扮ける収量执よび 果実品質. 園学雑. 73: 346-353.

伊藤大雄・蒔苗勝也・相馬洋一. 2010. リンゴ平棚仕立て

栽培に打ける側枝上の新梢摘心処理が花芽形成に及ぼ

す影響. 園芸学会東北支部平 22 要旨. 19-20.

神奈川県農業技術センター．2010. ニホンナシの樹体ジョ

イント仕立て.〈http://www.pref.kanagawa.jp/uploaded/ attachment/530382.pdf $\rangle$.

加藤 修 - 北口美代子 - 石井克文 - 関口美知 - 石田時昭. 1999. ニホンナシ花粉採取専用樹の仕立て法. 千葉農 試研報. 40: 9-21.

川尾尚史・久保浩之・角川敬造 - 奥野直行 - 北野欣信.

2005. カキ ‘刀根早生' の平棚栽培. 和歌山農林水総 技七研報. 6: 123-134.

倉橋孝夫・高橋国昭. 1994. リンゴ ‘ふじ の棚仕立て Y 字形整枝法と主幹形整枝法に打辇る生産力と果実品質 の比較. 園学雑. 63:305-311.
松波達也. 2003. ウメの平棚栽培法. 群馬園試研報. 8: 19-31.

松波達也・吉岡正明・関根幹弘. 1998. スモモの棚仕立て 栽培法. 群馬園試研報. 3:9-16.

岡田眞治・増田信篤. 2000. 露地モモの平棚仕立て栽培に 扣ける整枝法と作業効率. 熊本農研七研報. 9: 110 118.

岡田眞治・土田通彦・増田信篤・坂井健輔. 1996. 八ウス モモの平棚仕立て栽培に沶ける枝梢管理法と適正着果 量. 熊本農研七研報. 5: 141-152.

Robinson, T. N., A. N. Lakso and S. G. Carpenter. 1991. Canopy development, yield, and fruit quality of 'Empire' and 'Delicious' apple trees grown in four orchard production systems for ten years. J. Amer. Soc. Hort. Sci. 116: 179187.

塩崎雄之輔・菊池卓郎・今 満・藤井明彦・三上道彦. 1988. マルバカイドウ台半密植栽培の技術確立に関す る研究 第 1 報 半密植主幹形樹と疎植開心形樹の収 量, 品質の比較. 弘前大農学報. 49: 22-33.

Volpe, G., R. L. Bianco and M. Rieger. 2008. Carbon autonomy of peach shoots determined by ${ }^{13} \mathrm{C}$-photoassimilate transport. Tree Physiol. 28: 1805-1812.

横田 清. 2000. リンゴ樹の一生. p. 27-35. 果樹園芸大 百科 2 リンゴ. 農文協. 東京. 